\title{
Metode Simple Additive Weighting Dalam Seleksi Penerimaan Beasiswa Pada Sekolah Madrasah Ibtidaiyah Al Huda Jakarta Timur
}

\author{
Muhammad Rifki Ramadhan ${ }^{1}$, Arya Nandian Respati ${ }^{1}$, Bakri Syamsah ${ }^{1}$, Anna \\ Mukhayaroh ${ }^{1, *}$
}

* Korespondensi: e-mail: anna.auh@nusamandiri.ac.id

1 Sistem Informasi; Universitas Nusa Mandiri; Jl. Jatiwaringin Raya No. 2 Kelurahan Cipinang Melayu, Kecamatan Makasar, Jakarta Timur, telp. (021) 8005722; e- mail : 11200424@nusamandiri.ac.id, 11200426@nusamandiri.ac.id, 11200421@nusamandiri.ac.id anna.auh@nusamandiri.ac.id

$\begin{array}{ll}\text { Submitted } & : 25 \text { September } 2021 \\ \text { Revised } & : 23 \text { Oktober } 2021 \\ \text { Accepted } & : 8 \text { November } 2021 \\ \text { Published } & : 30 \text { November } 2021\end{array}$

\section{Abstract}

Educational institutions, especially Madrasah Ibtidaiyah, many scholarships are offered to prospective students, scholarships are also given to prospective students at Madrasah Ibtidaiyah Al Huda, East Jakarta, namely in the form of superior scholarships, several problems that often occur, for example the selection process is not accurate due to the large number of applicants who must register. according to the existing criteria, so that the selection process requires accuracy and time so this is not effective. Decision support applications are a way of dealing with the problem of determining scholarships at the Madrasah Ibtidaiyah. This application uses Simple Additive Weighing (SAW), chosen because this method determines the weight of each predetermined criterion then proceeds with the normalization process and continues with the ranking process to select the best alternative. The results of this study are a decision support system in the classification of scholarship recipients using the Simple Additive Weighting (SAW) method at Madrasah Ibtidaiyah Al Huda, East Jakarta based on a website with the results of the selected criteria C1 Academic Achievement, C2 Non-Academic Achievement, C3 Report Value, C4 Personality, C5 Parent's Dependent, C6 Parent's Income. Based on the results of research from the application of a decision support system in classifying scholarship recipients using the Simple Additive Weighting (SAW) method, it was successful so that it could be seen which students deserved the scholarship. This application makes it easier for Madrasah Ibtidaiyah in the new student admissions section to determine scholarship recipients according to existing criteria, faster and on target as expected compared to the previous system.

Keywords: Decision Support System, Scholarship, Simple Additive Weighting, Student.

\section{Abstrak}

Lembaga pendidikan khususnya Madrasah Ibtidaiyah banyak sekali beasiswa yang ditawarkan kepada calon siswa, pemberian beasiswa juga diberikan kepada calon siswa di Madrasah Ibtidaiyah Al Huda Jakarta Timur yaitu berupa beasiswa unggul mulia, beberapa permasalahan yang sering terjadi misal proses seleksi yang tidak akurat karena banyaknya pendaftar yang harus sesuai dengan kriteria yang ada, sehingga proses menyeleksi membutuhkan ketelitian dan waktu maka hal ini tidak efektif. Aplikasi pendukung keputusan merupakan cara menangani masalah penentuan beasiswa di Madrasah Ibtidaiyah tersebut. Aplikasi ini menggunakan Simple Additive Weigthing (SAW), dipilih karena metode ini menentuksn bobot dari setiap kriteria yang telah ditentukan kemudian dilanjutkan dengan proses normalisasi dan dilanjutkan dengan proses 
perangkingan untuk menyeleksi alternatif terbaik. Hasil penelitian ini berupa sistem penunjang keputusan dalam pengklasifikasian siswa penerima beasiswa dengan metode Simple Additive Weighting (SAW) di Madrasah Ibtidaiyah Al Huda Jakarta Timur berbasis website dengan hasil kriteria yang dipilih C1 Prestasi Akademik, C2 Prestasi Non Akademik, C3 Nilai Raport, C4 Kepribadian, C5 Tanggungan Orang Tua, C6 Pendapatan Orang Tua. Berdasarkan hasil penelitian dari aplikasi sistem penunjang keputusan dalam pengklasifikasian siswa penerima beasiswa dengan metode Simple Additive Weighting (SAW) ini berhasil sehingga dapat diketahui siswa yang layak mendapatkan beasiswa. Aplikasi ini memudahkan Madrasah Ibtidaiyah dibagian penerimaan mahasiswa baru untuk menentukan penerima beasiswa sesuai dengan kriteria yang ada, lebih cepat dan tepat sasaran sesuai yang diharapkan dibandingkan dengan sistem sebelumnya.

Kata kunci: Beasiswa, Simple Additive Weighting, Sistem Penunjangan Keputusan, Siswa.

\section{Pendahuluan}

Pendidikan merupakan hal yang sangat penting, negara perlu mendukung setiap warga negaranya untuk meraih pendidikan setinggi-tingginya. Hal ini didukung dengan adanya program pendidikan dan beasiswa gratis. Pemerintah mendukung semua warga negara dengan tingkat pendidikan tertinggi dan telah menetapkan program wajib belajar 12 tahun yang dimulai dengan sekolah dasar, menengah dan sekolah menengah atas atau sederajat. Dibutuhkan banyak uang untuk menyediakan pendidikan yang berkualitas. Oleh karena itu, semua siswa di semua satuan pendidikan berhak membayar uang sekolah bagi mereka yang orang tuanya tidak mampu untuk dididik dan menerima beasiswa bagi mereka yang mengalah (Safii, 2017).

Beasiswa adalah pendapatan pemegang beasiswa (di sini dalam bentuk hibah) dan membantu membantu pemegang beasiswa melalui biaya pelatihan (Hidayat, 2017). Beasiswa itu sendiri merupakan program kerja yang ada di semua lembaga pendidikan, dan beasiswa itu sendiri ditawarkan secara selektif sesuai dengan kriteria dan jenis hibah yang ditentukan. Beasiswa juga dapat diperoleh dari instansi pemerintah, dunia usaha dan yayasan yang diberikan secara cuma-cuma maupun dengan ikatan dinas setelah pendidikannya selesai (Damanik, 2020).

Sebagai salah satu lembaga pendidikan formal yang berada di bawah naungan Dinas Pendidikan Kota Jakarta Timur, Sekolah Madrasah Ibtidaiyah (MI Al Huda) Kota Jakarta Timur mendapatkan kuota bagi siswanya untuk mengikuti program pemberian beasiswa bagi siswa yang kurang mampu dan siswa yang berprestasi dari pemerintah. Oleh karena itu, beasiswa seharusnya diberikan kepada siswa yang layak dan pantas untuk mendapatkannya sesuai dengan ketentuan yang ditetapkan. Pada setiap periode tahun ajaran baru, staff kesiswaan menyeleksi siswa-siswi yang telah mendaftar sebagai penerima beasiswa. Proses penyeleksian ini membutuhkan ketelitian dan waktu yang lama, karena setiap data siswa akan dibandingkan satu persatu sesuai dengan kriteria yang telah ditetapkan, dan juga rentan akan terjadinya kesalahan manusia (human error). Sedangkan di Madrasah Ibtidaiyah Al Huda belum diterapkan suatu metode dalam membantu menyeleksi siswa penerima beasiswa, dan proses seleksi tersebut masih dilakukan secara manual dengan cara membandingkan satu persatu siswa calon penerima beasiswanya.

Teknologi berperan penting dalam menyelesaikan pekerjaan manusia. Komputer sebagai alternatif perangkat teknologi canggih. Hal ini memungkinkan komputer untuk melakukan tugas, memproses sejumlah besar arus informasi, dan membuat keputusan terbaik. 
Sebagai alat penunjang keberhasilan pada masalah yang diangkat oleh peneliti, maka peneliti menggunakan system penunjang keputusan. Sistem Pendukung Keputusan (SPK) adalah program komputerisasi yang digunakan untuk mendukung keputusan, penilaian, dan tindakan dalam suatu organisasi atau perusahaan. SPK menyaring dan menganalisis sejumlah besar data dan mengumpulkan sejumlah besar informasi yang dapat digunakan dalam pemecahan masalah dan pengambilan keputusan (Saputra \& Aprilian, 2020). SPK menyediakan informasi untuk membantu pengambilan keputusan yang tidak terstruktur bagaimana keputusan seharusnya dibuat (Akram \& Ihsan, 2019). Ada berbagai macam metode yang dapat digunakan dalam pengimplementasian SPK ini, namun peneliti menggunakan metode Simple Additive Weighting (SAW) dan metode Technique for Order Preference by Similarity to Ideal Solution (TOPSIS) sebagai metode perbandingan.

\section{Metode Penelitian}

Metode penelitian pada dasarnya adalah cara ilmiah untuk mendapatkan data dengan tujuan dan kegunaan tertentu. Metode penelitian pada dasarnya adalah cara ilmiah untuk mendapatkan data dengan tujuan dan kegunaan tertentu. Metode yang digunakan ialah menggunakan metode Simple Additive Weighting (SAW) dan Metode Technique for Order Preference by Similarity to Ideal Solution (TOPSIS) yang digunakan sebagai metode pendukung keputusan dalam proses seleksi calon penerima beasiswa. Kemudian pembahasan kedua mengenai metode waterfall yang digunakan sebagai metode pendekatan dalam mengembangkan aplikasi sistem pendukung keputusan.

Metode SAW cocok untuk menyelesaikan permasalahan pemilihan calon siswa penerima beasiswa karena menggunakan penjumlahan berbobot pada setiap kriteria (Topadang et al., 2020). Adapun beberapa tahapan dari metode SAW agar dapat menghasilkan keputusan menurut (Khasanah \& Rofiah, 2019) diantaranya sebagai berikut (a) Menentukan alternatif; (b) Menentukan kriteria penilaian; (c) Menentukan kecocokan alternatif terhadap setiap kriteria; (d) Membuat normalisasi matriks; (e) Membuat matriks ternormalisasi; (f) Menetukan perangkingan setiap alternatif sampai akhirnya diperoleh hasil keputusan.

Prosedur perhitungan dengan Metode TOPSIS sebagai berikut (a) Menentukan matrik ternormalisasi; (b) Pembobotan matrik; (c) Menghitung matriks solusi ideal positif dan matrik solusi ideal negatif; (d) Nilai solusi ideal positif $\left(A_{+}\right)$dan nilai solusi negatif $(A-)$ berdasarkan matrik keputusan ternormalisasi terbobot Y; (e) Menghitung jarak antara nilai setiap alternatif dengan solusi ideal positif ( $\left.D_{+}\right)$dan jarak antara nilai setiap alternatif dengan solusi ideal negatif (D-). Jarak antar alternatif dengan solusi ideal positif (A+); (f) Menghitung nilai preferensi untuk setiap siswa (Vi).

\subsection{Tahapan Penelitian}

Tahapan-tahapan proses yang peneliti lakukan guna menyelesaikan penelitian ini, dimulai dari identifikasi masalah, studi pustaka, pengumpulan data, pembuatan model, uji coba skenario alternatif, analisa hasil, dan kesimpulan seperti pada gambar 1 . 


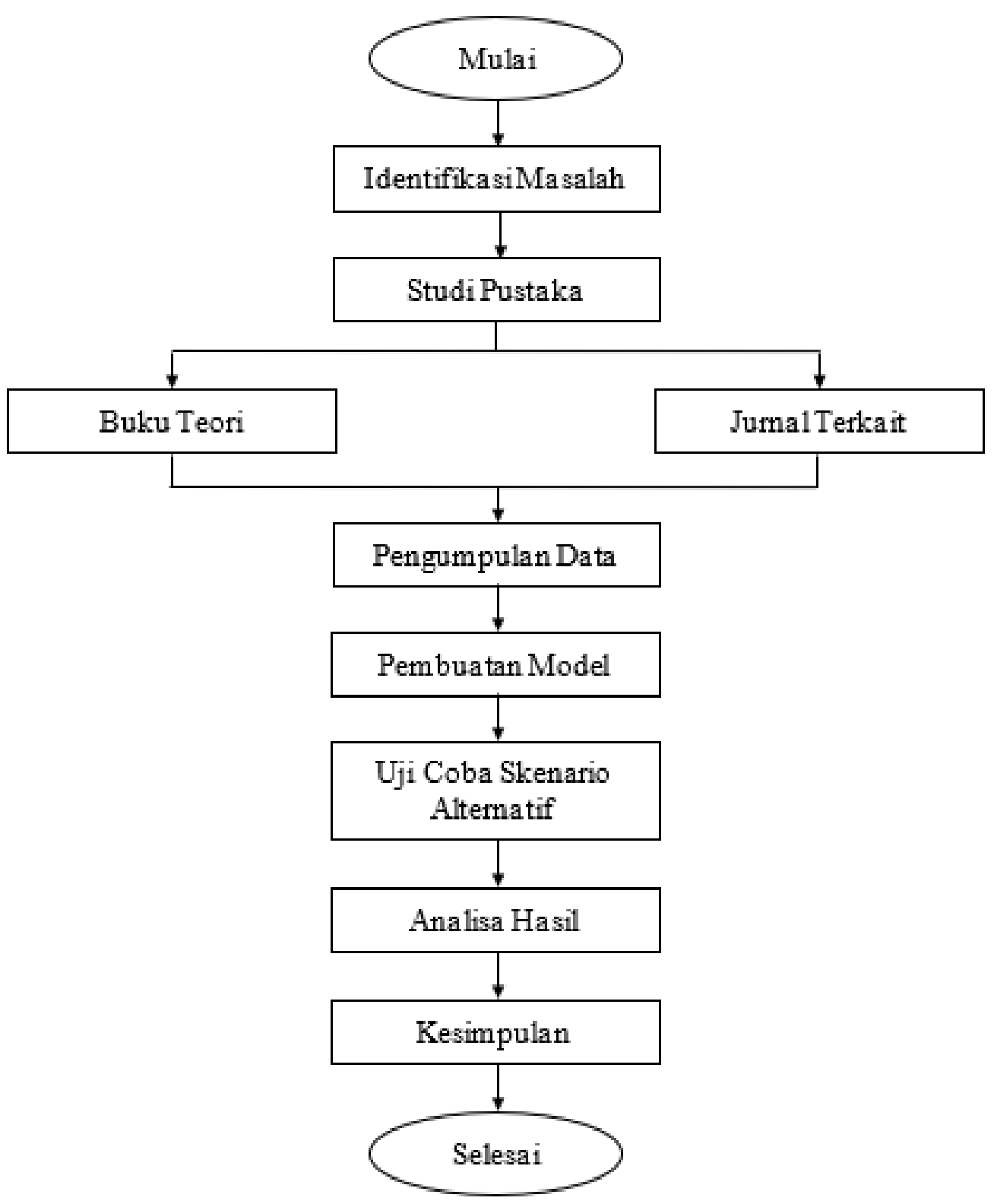

Sumber: Hasil Penelitian (2021)

Gambar 1. Tahapan Penelitian

Identifikasi masalah, hal yang mendasari adanya penelitian penelitian ini ialah masalah yang diangkat mengenai penyeleksian penerimaan beasiswa pada Sekolah Madrasah Ibtidaiyah (MI Al Huda) Kota Jakarta Timur. Peneliti menyadari bahwa sistem yang digunakan masih belum cukup efisien dan dapat ditingkatkan, solusi yang ditawarkan yaitu dengan menggunakan aplikasi SPK menggunakan metode Simple Additive Weighting (SAW).

Studi pustaka, untuk menunjang penelitian penelitian ini, maka dibutuhkan jurnal nasional maupun internasional yang terkait. Serta buku-buku yang berkaitan dengan masalah yang diangkat. Studi Pustaka yang peneliti kutip berkaitan dengan proses penerimaan beasiswa serta metode Simple Additive Weighting (SAW). 
Pengumpulan data, yang didapatkan dari hasil observasi pada instansi terkait, wawancara terhadap pihak yang bertanggung jawab terhadap penyeleksian penerimaan beasiswa, serta studi pustaka yang peneliti lakukan.

Pembuatan model, rancangan sistem yang akan dibuat berdasarkan dari data yang telah dikumpulkan. Rancangan model ini kemudian akan diterapkan kedalam pembuatan aplikasi yang menjadi hasil akhir dari penelitian ini.

Uji coba skenario alternatif, setelah data didapatkan dan perumusan model pencarian data menggunakan metode SAW telah dibuat, maka dilanjutkan ke tahapan uji coba. Pada tahapan ini peneliti melihat apakah perumusan model telah sesuai guna menemukan data yang diinginkan.

Analisa hasil, setelah dilakukan uji coba terhadap data yang peneliti peroleh, maka selanjutnya dilakukan analisa terhadap hasil yang didapatkan. Apakah hasil sudah sesuai dengan yang diharapkan atau belum sesuai target. Apabila sudah sesuai maka dilanjutkan kepada tahap akhir penelitian.

Kesimpulan, setelah semua telah sesuai dengan apa yang direncanakan, maka dilakukan penyusunan penelitian ini. Peneliti juga mencoba untuk menerapkan sistem baru yang telah dibangun guna membantu meng-efektifkan dan mengefisienkan proses penyeleksian penerimaan beasiswa pada Sekolah Madrasah Ibtidaiyah (MI Al Huda) Kota Jakarta Timur.

\subsection{Sistem Penunjang Keputusan}

Sistem pendukung keputusan (SPK) bertindak sebagai sistem berbantuan komputer yang mendukung proses pengambilan keputusan. SPK sebagai sistem informasi berbasis komputer yang adaptif, interaktif dan fleksibel yang dikembangkan secara khusus untuk mendukung penyelesaian masalah manajemen yang tidak terstruktur dan meningkatkan kualitas pengambilan keputusan. Oleh karena itu, Anda dapat menetapkan definisi SPK. Ini adalah adaptif, fleksibel, sistem berbasis komputer interaktif yang digunakan untuk memecahkan masalah tidak terstruktur untuk menambah nilai pengambilan keputusan (Taufiq, 2017).

\subsection{Simple Additive Weighting (SAW)}

Metode Simple Additive Weighting biasa disingkat SAW pada dasarnya adalah mencari penjumlahan terbobot dari rating kinerja pada setiap alternatif pada semua atribut. Metode ini membutuhkan proses normalisasi matriks keputusan ke suatu skala yang dapat diperbandingkan dengan semua rating alternatif yang ada. Inti dari metode SAW adalah menentukan nilai bobot untuk setiap atribut kemudian dilanjutkan dengan proses klasifikasi yang menyeleksi alternatif-alternatif yang diberikan (Sari, 2018).

\subsection{Technique for Order Preference by Similarity to Ideal Solution (TOPSIS)}

TOPSIS menawarkan solusi dari serangkaian kemungkinan alternatif yang membandingkan setiap alternatif dengan alternatif terbaik dan alternatif terburuk di antara 
alternatif masalah. Alternatif-alternatif yang dievaluasi kemudian menjadi acuan bagi pengambil keputusan untuk memilih solusi terbaik yang diinginkan (Poningsih et al, 2020).

\section{Hasil dan Pembahasan}

Hasil yang peneliti dapatkan melalui narasumber yang telah diwawancarai serta hasil dan pembahasan yang memuat pemecahan masalah yang berhasil dilakukan, peneliti terhadap hasil yang diperoleh.

\subsection{Data Siswa}

Data dari para siswa/i yang kemudian akan diolah untuk dapat menentukan calon penerima beasiswa yang paling sesuai menggunakan metode Simple Additive Weighting (SAW).

Tabel 1. Data Siswa/i Calon Penerima Beasiswa

\begin{tabular}{clccccc}
\hline NIS & Nama & $\begin{array}{c}\text { Jenis } \\
\text { Kelamin }\end{array}$ & Alamat & $\begin{array}{c}\text { Pekerjaan } \\
\text { Orang Tua }\end{array}$ & $\begin{array}{c}\text { Penghasilan } \\
\text { Orang Tua }\end{array}$ & $\begin{array}{c}\text { Jumlah } \\
\text { Saudara }\end{array}$ \\
\hline 170556 & Aisyah Rizkyanti Anna & $\mathrm{P}$ & Buaran & Swasta & Rp. 3.000.000 & 1 \\
\hline 170562 & Altan HananKautsar & $\mathrm{L}$ & Pondok Kopi & Swasta & Rp. 2.000.000 & 1 \\
\hline 170569 & Boy Melvianto & $\mathrm{L}$ & Cakung & Swasta & Rp. 3.500.000 & 0 \\
\hline 170599 & Isma Maulidha & $\mathrm{P}$ & Pulogebang & PNS & Rp. 4.000.000 & 2 \\
\hline 170600 & Jesika RahmaFatria & $\mathrm{P}$ & Rawa Bebek & PNS & Rp. 5.500.000 & 2 \\
\hline
\end{tabular}

Sumber: Hasil Penelitian (2021)

Selanjutnya adalah data prestasi para siswa/i calon penerima beasiswa serta penilaian secara individu semasa disekolah menurut wali kelas yang bersangkutan dengan siswa tersebut.

Tabel 2. Data Prestasi dan Penilaian Kepribadian Siswa/i

\begin{tabular}{clllll}
\hline NIS & \multicolumn{1}{c}{ Nama } & Prestasi Akademik & $\begin{array}{l}\text { Prestasi Non } \\
\text { Akademik }\end{array}$ & Nilai Rapor & Kepribadian \\
\hline 170556 & $\begin{array}{l}\text { Aisyah Rizkyanti } \\
\text { Anna }\end{array}$ & $\begin{array}{l}\text { Berprestasi Tingkat } \\
\text { Sekolah }\end{array}$ & Tidak Berprestasi & Ranking 3 & Baik \\
\hline 170562 & Altan HananKautsar & $\begin{array}{l}\text { BerprestasiTingkat } \\
\text { Kabupaten }\end{array}$ & Tidak Berprestasi & Ranking 1 & Sangat Baik \\
\hline 170569 & Boy Melvianto & Tidak Berprestasi & $\begin{array}{l}\text { BerprestasiTingkat } \\
\text { Sekolah }\end{array}$ & $\begin{array}{l}\text { Ranking } \\
\text { 4Ke Atas }\end{array}$ & Cukup \\
\hline 170599 & Isma Maulidha & Berprestasi Tingkat & Tidak Berprestasi & Ranking & Baik \\
& & Sekolah & Rerprestasi Tingkat & Ranking & Baik \\
\hline 170600 & Jesika Rahma Fatria Tidak Berprestasi & Kabupaten & A Ke & \\
& & & Atas & \\
\hline
\end{tabular}

Sumber: Hasil Penelitian (2021)

\subsection{Pembobotan dan Kriteria}

Pada tabel 3 adalah kriteria pembobotan yang digunakan untuk menentukan calon penerima beasiswa pada Madrasah Ibtidaiyah Al Huda.

Tabel 3. Kriteria Pembobotan

\begin{tabular}{ccccccc}
\hline $\begin{array}{c}\text { Prestasi } \\
\text { Akademik }\end{array}$ & $\begin{array}{c}\text { Prestasi } \\
\text { Non } \\
\text { Akademik }\end{array}$ & $\begin{array}{c}\text { Nilai } \\
\text { Rapor }\end{array}$ & Kepribadian & $\begin{array}{c}\text { Tanggungan } \\
\text { Orang Tua }\end{array}$ & $\begin{array}{c}\text { Pendapatan } \\
\text { Orang Tua }\end{array}$ & Total \\
\hline $30 \%$ & $20 \%$ & $10 \%$ & $20 \%$ & $10 \%$ & $10 \%$ & $100 \%$ \\
\hline 0,3 & 0,2 & 0,1 & 0,2 & 0,1 & 0,1 & 1 \\
\hline
\end{tabular}

Sumber: Hasil Penelitian (2021) 
Adapun nilai per kriteria yang menjadi bahan untuk pertimbangan panitia penyeleksi beasiswa seperti yang ditunjukan pada tabel 4 .

Tabel 4. Himpunan Nilai per Kriteria

\begin{tabular}{|c|c|c|}
\hline Kriteria & Himpunan Kriteria & Nilai \\
\hline \multirow{5}{*}{ Prestasi Akademik } & Tidak Berprestasi & 1 \\
\hline & Berprestasi Tingkat Sekolah & 2 \\
\hline & Berprestasi Tingkat Kabupaten & 3 \\
\hline & Berprestasi Tingkat Provinsi & 4 \\
\hline & Berprestasi Tingkat Nasional & 5 \\
\hline \multirow{5}{*}{ Prestasi Non Akademik } & Tidak Berprestasi & 1 \\
\hline & Berprestasi Tingkat Sekolah & 2 \\
\hline & Berprestasi Tingkat Kabupaten & 3 \\
\hline & Berprestasi Tingkat Provinsi & 4 \\
\hline & Berprestasi Tingkat Nasional & 5 \\
\hline \multirow{4}{*}{ Nilai Rapor } & Ranking 4 ke Atas & 1 \\
\hline & Ranking 3 & 2 \\
\hline & Ranking 2 & 3 \\
\hline & Ranking 1 & 4 \\
\hline \multirow{5}{*}{ Kepribadian } & Sangat Kurang & 1 \\
\hline & Kurang Baik & 2 \\
\hline & Cukup & 3 \\
\hline & Baik & 4 \\
\hline & Sangat Baik & 5 \\
\hline \multirow{5}{*}{ Pendapatan Orang Tua } & Lebih dari Rp. 10.000 .000 & 1 \\
\hline & Rp. 5.000 .000 - Rp. 10.000 .000 & 2 \\
\hline & Rp. 2.500 .000 - Rp. 5.000 .000 & 3 \\
\hline & Rp. 1.000 .000 - Rp. 2.500 .000 & 4 \\
\hline & Kurang dari Rp. 1.000 .000 & 5 \\
\hline \multirow{4}{*}{ Tanggungan Orang Tua } & 1 Anak & 1 \\
\hline & 2 Anak & 2 \\
\hline & 3 Anak & 3 \\
\hline & 4 Anak atau Lebih & 4 \\
\hline
\end{tabular}

Sumber: Hasil Penelitian (2021)

\subsection{Nilai Siswa Berdasarkan Kriteria}

Pada tabel 5 ini ada nilai para siswa/i calon penerima beasiswa berdasarkan nilai per kriteria yang telah ditentukan.

Tabel 5. Nilai Siswa per Kriteria

\begin{tabular}{|c|c|c|c|c|c|c|}
\hline Nama & $\begin{array}{c}\text { Prestasi } \\
\text { Akademik }\end{array}$ & $\begin{array}{c}\text { Prestasi Non } \\
\text { Akademik }\end{array}$ & Nilai Rapor & Kepribadian & $\begin{array}{c}\text { Tanggungan } \\
\text { Orang Tua }\end{array}$ & $\begin{array}{c}\text { Pendapatan } \\
\text { Orang Tua }\end{array}$ \\
\hline Aisyah Rizkyanti Anna & 2 & 1 & 2 & 4 & 2 & 3 \\
\hline Altan Hanan Kautsar & 3 & 1 & 4 & 5 & 2 & 4 \\
\hline Boy Melvianto & 1 & 2 & 1 & 3 & 1 & 3 \\
\hline Isma Maulidha & 2 & 1 & 3 & 4 & 3 & 3 \\
\hline Jesika Rahma Fatria & 1 & 3 & 1 & 4 & 3 & 2 \\
\hline
\end{tabular}

Sumber: Hasil Penelitian (2021)

Kemudian nilai pada tabel di atas kita normalisasi kan menggunakan rumus normalisasi pada metode Simple Additive Weighting (SAW):

$$
\begin{aligned}
\mathbf{R}_{\mathrm{ij}} & =\mathbf{X}_{\mathrm{ij}} / \operatorname{Max}\left\{\mathbf{X}_{\mathrm{ij}}\right\} \quad \text { (Jika atribut kriteria berupa Benefit) } \\
\mathrm{R}_{\mathrm{ij}} & =\operatorname{Min}\left\{\mathrm{X}_{\mathrm{ij}}\right\} \mathrm{X}_{\mathrm{ij}} \quad \text { (Jika atribut kriteria berupa Cost) }
\end{aligned}
$$

Dimana :

$\mathrm{R}_{\mathrm{ij}} \quad=$ Rating kinerja yang telah ternormalisasi

$\mathrm{X}_{\mathrm{ij}} \quad=$ Nilai yang akan di normalisasi

$\operatorname{Max}\left\{\mathrm{Xi}_{\mathrm{i}}\right\}=$ Nilai Maksimal pada kriteria 
$\operatorname{Min}\left\{\mathrm{X}_{\mathrm{ij}}\right\}=$ Nilai Minimum pada kriteria

Dengan menggunakan rumus 1, maka hasil normalisasi pada tabel Siswa per Kriteria adalah seperti pada tabel 6 .

Tabel 6. Hasil Normalisasi

\begin{tabular}{|c|c|c|c|c|c|c|}
\hline Nama & $\begin{array}{c}\text { Prestasi } \\
\text { Akademik }\end{array}$ & $\begin{array}{l}\text { Prestasi } \\
\text { Non } \\
\text { Akademik }\end{array}$ & $\begin{array}{l}\text { Nilai } \\
\text { Rapor }\end{array}$ & Kepribadian & $\begin{array}{r}\text { Tanggungan } \\
\text { Orang Tua }\end{array}$ & $\begin{array}{c}\text { Pendapatan } \\
\text { Orang Tua }\end{array}$ \\
\hline Aisyah RizkyantiAnna & 0,67 & 0,33 & 0,50 & 0,80 & 0,67 & 0,67 \\
\hline Altan HananKautsar & 1,00 & 0,33 & 1,00 & 1,00 & 0,67 & 0,50 \\
\hline Boy Melvianto & 0,33 & 0,67 & 0,25 & 0,60 & 0,33 & 0,67 \\
\hline Isma Maulidha & 0,67 & 0,33 & 0,75 & 0,80 & 1,00 & 0,67 \\
\hline Jesika RahmaFatria & 0,33 & 1,00 & 0,25 & 0,80 & 1,00 & 1,00 \\
\hline
\end{tabular}

Kolom berwarna hijau menandakan Benefit, sedangkan kolom berwarna merah menandakan Cost.

Normalisasi

\begin{tabular}{|c|c|c|c|c|c|c|c|}
\hline NIS & NAMA SISWA & $\begin{array}{l}\text { Prestasi } \\
\text { Akademik } \\
\text { (30) }\end{array}$ & $\begin{array}{l}\text { Prestasi } \\
\text { Non } \\
\text { Akademik } \\
(20)\end{array}$ & $\begin{array}{l}\text { Nilai } \\
\text { Rapor } \\
\text { (10) }\end{array}$ & $\begin{array}{l}\text { Kepribadian } \\
\text { (20) }\end{array}$ & $\begin{array}{l}\text { Pendapatan } \\
\text { Orang } \\
\text { Tua } \\
\text { (10) }\end{array}$ & $\begin{array}{l}\text { Tanggungan } \\
\text { Orang } \\
\text { Tua } \\
\text { (10) }\end{array}$ \\
\hline 170556 & Aisyah Rizkyanti Anna & 0.67 & 0.33 & 0.50 & 0.80 & 0.67 & 0.67 \\
\hline 170562 & Altan Hanan Kautsar & 1.00 & 0.33 & 1.00 & 1.00 & 0.50 & 0.67 \\
\hline 170569 & Boy Melvianto & 0.33 & 0.67 & 0.25 & 0.60 & 0.67 & 0.33 \\
\hline 170599 & Isma Maulidha & 0.67 & 0.33 & 0.75 & 0.80 & 0.67 & 1.00 \\
\hline 170600 & Jesika Rahma Fatria & 0.33 & 1.00 & 0.25 & 0.80 & 1.00 & 1.00 \\
\hline
\end{tabular}

Sumber: Hasil Penelitian (2021)

Gambar 1. Tampilan Data Normalisasi pada Aplikasi

\subsection{Total Nilai dan Hasil Seleksi}

Untuk menentukan total nilai, pertama-tama nilai indeks yang telah ternormalisasi dikalikan dengan nilai pembobotan.

Tabel 7. Nilai Normalisasi dikali Bobot Kriteria

\begin{tabular}{lcccccc}
\hline \multicolumn{1}{c}{ Nama } & $\begin{array}{c}\text { C1 } \\
(30 \%)\end{array}$ & $\begin{array}{c}\text { C2 } \\
(20 \%)\end{array}$ & $\begin{array}{c}\text { C3 } \\
(10 \%)\end{array}$ & $\begin{array}{c}\text { C4 } \\
(20 \%)\end{array}$ & $\begin{array}{c}\text { C5 } \\
(10 \%)\end{array}$ & $\begin{array}{c}\text { C6 } \\
(10 \%)\end{array}$ \\
\hline Aisyah RizkyantiAnna & $0,67 \times 0,3$ & $0,33 \times 0,2$ & $0,50 \times 0,1$ & $0,80 \times 0,2$ & $0,67 \times 0,1$ & $0,67 \times 0,1$ \\
\hline Altan HananKautsar & $1,00 \times 0,3$ & $0,33 \times 0,2$ & $1,00 \times 0,1$ & $1,00 \times 0,2$ & $0,67 \times 0,1$ & $0,50 \times 0,1$ \\
\hline Boy Melvianto & $0,33 \times 0,3$ & $0,67 \times 0,2$ & $0,25 \times 0,1$ & $0,60 \times 0,2$ & $0,33 \times 0,1$ & $0,67 \times 0,1$ \\
\hline Isma Maulidha & $0,67 \times 0,3$ & $0,33 \times 0,2$ & $0,75 \times 0,1$ & $0,80 \times 0,2$ & $1,00 \times 0,1$ & $0,67 \times 0,1$ \\
\hline Jesika RahmaFatria & $0,33 \times 0,3$ & $1,00 \times 0,2$ & $0,25 \times 0,1$ & $0,80 \times 0,2$ & $1,00 \times 0,1$ & $1,00 \times 0,1$ \\
\hline Sumber: Hasil Penelitian (2021) & & & & &
\end{tabular}

Selanjutnya jumlahkan tiap hasil yang didapatkan per- individunya sebagaimana terlihat hasilnya pada tabel 8.

Tabel 8. Hasil Nilai Normalisasi dikali Bobot Kriteria

\begin{tabular}{lcccccc}
\hline \multicolumn{1}{c}{ Nama } & $\begin{array}{c}\text { C1 } \\
(30 \%)\end{array}$ & $\begin{array}{c}\text { C2 } \\
(20 \%)\end{array}$ & $\begin{array}{c}\text { C3 } \\
(10 \%)\end{array}$ & $\begin{array}{c}\text { C4 } \\
(20 \%)\end{array}$ & $\begin{array}{c}\text { C5 } \\
(10 \%)\end{array}$ & $\begin{array}{c}\text { C6 } \\
(10 \%)\end{array}$ \\
\hline Aisyah RizkyantiAnna & 0,201 & 0,066 & 0,05 & 0,16 & 0,067 & 0,067 \\
\hline Altan HananKautsar & 0,3 & 0,066 & 0,1 & 0,2 & 0,067 & 0,05 \\
\hline Boy Melvianto & 0,099 & 0,134 & 0,025 & 0,12 & 0,033 & 0,067 \\
\hline Isma Maulidha & 0,201 & 0,066 & 0,075 & 0,16 & 0,1 & 0,067 \\
\hline Jesika RahmaFatria & 0,099 & 0,2 & 0,025 & 0,16 & 0,1 & 0,1 \\
\hline
\end{tabular}

Sumber: Hasil Penelitian (2021) 
Berdasarkan hasil pengolahan data yang didapat, maka masing-masing calon penerima beasiswa dapat dirankingkan berikut pada tabel 9 .

Tabel 9. Nilai Calon Penerima Beasiswa

\begin{tabular}{clcc}
\hline NIS & \multicolumn{1}{c}{ Nama } & Total Nilai & Ranking \\
\hline 170556 & Aisyah Rizkyanti Anna & 0,611 & 4 \\
\hline 170562 & Altan Hanan Kautsar & 0,783 & 1 \\
\hline 170569 & Boy Melvianto & 0,478 & 5 \\
\hline 170599 & Isma Maulidha & 0,669 & 3 \\
\hline 170600 & Jesika Rahma Fatria & 0,684 & 2 \\
\hline
\end{tabular}

Sumber: Hasil Penelitian (2021)

Setelah mendapatkan data yang diinginkan, maka dapat disimpulkan bahwa yang berhak mendapatkan Beasiswa pada Madrasah Ibtidaiyah Al Huda adalah Altan Hanan Kautsar dengan perolehan Nilai sebesar 0,783 .

Hasil

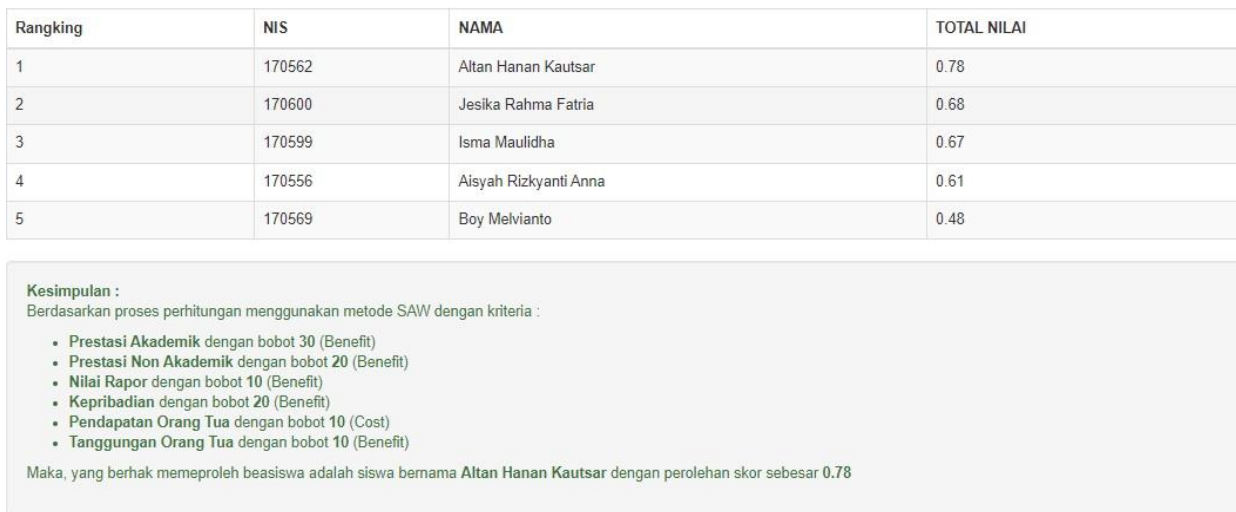

Sumber: Hasil Penelitian (2021)

Gambar 3. Tampilan Hasil yang diperoleh pada Aplikasi

\section{Kesimpulan}

Penerapan sistem pendukung keputusan dalam proses seleksi penerima beasiswa dikembangkan dengan metode Simple Additive Weighting (SAW) sehingga memberikan hasil keputusan yang tepat, akurat dan beasiswa tersebut jatuh kepada siswa yang berhak menerimanya. Metode SAW dapat memberikan hasil melalui beberapa tahapan diantaranya menentukan alternatif, menentukan kriteira, rating kecocokan alternatif terhadap setiap kriteria, normalisasi matriks, membentuk matriks ternormalisasi, perangkingan setiap alternatif dan terakhir dapat diketahui hasil seleksi penerima beasiswa berdasarkan nilai alternatif tertinggi.

\section{Daftar Pustaka}

Akram, R., \& Ihsan, A. (2019). Perancangan Sistem Penerimaan Beasiswa Dengan Metode Simple Additive Weighting ( SAW ). Jurnal Energi Listrik, 08, 6-10.

Damanik, B. (2020). Metode Simple Additive Weighting ( SAW ) Dalam Seleksi Penerima Beasiswa Bagi Mahasiswa. Jurnal Mahajana Informasi, 5(2), 3-8.

Hidayat, R. (2017). Metode Simple Additive Weighting Sebagai Sistem Pendukung Keputusan 
Penerima Beasiswa Murid Berprestasi. SinkrOn (Jurnal \& Penelitian Teknik Informatika), 2(2), 13-17.

Khasanah, F. N;Rofiah, S. (2019). Sistem Seleksi Penerimaan Beasiswa Menggunakan Metode Pendukung Keputusan Simple Additive Weighting. In Seminar Nasional APTIKOM.

Poningsih et al. (2020). Sistem Pendukung Keputusan: Penerapan dan 10 Contoh Studi Kasus (1st ed.). Yayasan Kita Menulis.

Safii, M. (2017). Sistem Pendukung Keputusan Penerima Beasiswa PPA Dan BBM Menggunakan Metode Simple Additive Weighting (SAW). Jurasik (Jurnal Riset Sistem Informasi Dan Teknik Informatika), 2(1), 75. https://doi.org/10.30645/jurasik.v2i1.21

Saputra, M. H. K., \& Aprilian, L. V. (2020). Belajar Cepat Metode SAW. Kreatif Industri Nusantara.

Sari, F. (2018). Metode Dalam Pengambilan Keputusan (H. A. Susanto (ed.); 1st ed.). CV. Budi Utama.

Taufiq, R. (2017). Perancangan Sistem Pendukung Keputusan Penerimaan Beasiswa Mengunakan Metode Saw Pada Smp Yuppentek 1 Legok. Jurnal Teknik, 6(2). https://doi.org/10.31000/jt.v6i2.447

Topadang, A., Irwansyah, I., \& Safruddin, S. (2020). Penerapan Metode Simple Additive Weighting(SAW) Untuk Pemilihan Beasiswa Kurang Mampu Pada Sekolah Dasar Katolik Hati Kudus Samarinda. Just TI (Jurnal Sains Terapan Teknologi Informasi), 12(2), 66. https://doi.org/10.46964/justti.v12i2.377 